\title{
1 Agency and practice in the making of global cities: towards a renewed research agenda
}

\author{
Michael Hoyler, Christof Parnreiter and
} Allan Watson

\subsection{INTRODUCTION}

Since Saskia Sassen's (1991) seminal book The Global City, a heterogeneous body of literature has developed under the umbrella of 'global' or 'world' city research. Broadly, one might draw a distinction between economic approaches and urban studies approaches to understanding the global city. With regards to the former, one major strand of global cities research has been constituted by quantitative assessments of global urban networks, for example in research on the 'world city network' using an 'interlocking network model' for estimating the connectivities of cities (Taylor, 2004). From an urban studies perspective, a significant body of work has developed which seeks to understand the relations between global city formation or globalization processes more broadly and urban phenomena, such as the restructuring of labour and real estate markets, income polarization, and immigration (Derudder et al., 2012).

While these two threads of the global city literature have deepened our knowledge of urban economic, spatial and social dynamics under the impact of globalization, and of the cross-border connections of world cities and their individual trajectories, many of these studies have bypassed the theoretical core of the global city paradigm, namely a city's function in the management and governance of the world economy. Relatively few studies have examined how intermediaries, identified by Sassen (2018) as the key actors of global city formation, operate to articulate and control economic activities at various scales (e.g. Rossi et al., 2007; Hanssens et al., 2012; Jacobs, 2014; Parnreiter, 2010, 2015; Boussebaa, 2015). As Bassens and van Meeteren (2015, p. 753) point out, the 'overall consensus is that capitalist command and control is exercised from a limited set of cities which function as nodes for transnational flows of capital, goods, people, 
and information, from which actors operating from these places draw their power'. Indeed, as Sassen suggests (2001, p. 347-348, emphasis added), 'A key purpose of the model is to conceive of economic globalization not just as capital flows, but as the work of coordinating, managing and servicing these flows. ... The global city network is the operational scaffolding of ... the global economy'.

For us, the global city concept as proposed by Friedmann (1986) and Sassen (1991) consists of four interrelated claims (Parnreiter, 2014): (i) global cities are clusters for advanced producer services (APS) (producing localized externalities); (ii) global cities operate in a worldwide network constituted through the cross-border organizational structures of APS firms (producing network externalities); (iii) global cities are centres for the management of the world economy; and (iv) global cities are centres for the governance of the world economy. Inter-firm relations (between APS firms and their clients) are thus critical in this conceptualization.

What implications arise from such a perspective on global cities? If the key functional linkages in global city formation are those between APS and their client firms, then the main agents in the formation of global cities and their networks are APS. While this is, of course, a widely accepted premise of Sassen's (1991) thesis, such an economic geography reading of the global city concept is nevertheless by no means a majoritarian interpretation. Further, if this premise holds, then the key practices in global city making are the servicing of the clients, and, in particular, the servicing that contributes to the smooth functioning (the management task of global cities) and to the governing (the control task) of global commodity chains (GCCs). In Sassen's words (2001, pp. 359, 361; emphasis added), the 'key indicator of global city status is whether a city contains the capabilities for servicing, managing, and financing the global operations of firms and markets. ... The question is whether coordination and specialized servicing of global firms and markets is taking place.'

There are two important conceptual and methodological implications to this. The first is that global city research necessarily has to adopt a relational approach: the very idea of a world/global city as expressed by Friedmann and Sassen only makes sense if these cities are seen in a relational perspective, tied to each other (Taylor, 2004), but also to all the 'ordinary' cities (Robinson, 2006) where production for the world market is carried out. The second implication is that global city researchers need to adopt, in addition to (rather than instead of) the measurement of external city connections (e.g. Taylor et al., 2011; Hanssens et al., 2011), qualitative research strategies in order to appropriately assess the management and governance relations between APS firms and their clients. Watson and Beaverstock (2014) forcefully argue that the emphasis on analysing the 
structure of the world city network has gone at the expense of examining and explaining agency in global cities. Such pleas to focus on agency are very much in line with Sassen's call for studying 'the practices that constitute what we call economic globalization and global control' (2001, p. xxii; original emphasis). As Bassens and van Meeteren (2015, p. 755) argue, 'command and control has been ... too crude a notion to specify the relation between world cities and the exercise of power'. Instead, 'it is the assemblage of resources and abilities that enables command and control in world cities'. We therefore need to focus on 'the practices of financial and business elites ... that involve modes of power such as manipulation, seduction or inducement other than top-down domination and control' (emphasis added). As Sassen (2018, p. 3; emphasis in original) notes, 'The global city function is made, and that process of making is complex and multi-faceted'.

With this in mind, the aim of the book is to begin the task of setting a renewed agenda for world cities research that centres on the economic actors and individual and collective economic practices that lie at the heart of global city and world city network formation. We start from a conceptualization of global cities as places from where the world economy is managed and controlled through the practices of advanced producer service firms and, more specifically, the professionals operating within them. We term these actors global city makers. An explicit objective is to consider how current approaches within economic geography can enhance our understanding of the role of economic actors in the world city network. Relational thinking in world cities research has developed in parallel to a relational turn in economic geography yet there has been little mutual engagement (Watson and Beaverstock, 2014). In this book, we are interested in how a relational economic geography perspective can contribute to relational understandings of the world city network.

To achieve this goal, this book brings together contributions that engage critically and constructively with current global cities research from an economic geography perspective, and which suggest innovative avenues for its theoretical, methodological and empirical development. The book's chapters examine the role of APS in the management and governance of the world economy, with a focus on financial services, management consultancy, real estate, commodity trading and maritime industries. The contributions draw on a wide range of methods, including interviews, discourse analysis and quantitative data analysis to critically examine the practices through which key economic actors are engaged in making (and un-making) global cities. The studies are located across the world, including major global cities such as Sassen's (1991) original global city triad of New York, London and Tokyo, as well as emerging global cities in 
the Global South (Mexico and Mumbai) and second-tier European cities (Amsterdam and Hamburg).

\subsection{APPROACHES TO RELATIONALITY AND AGENCY}

The late 1990s saw the establishment of a relational turn in the study of world cities. This approach argued that cities were not defined by what was contained within them, but rather what flowed through them; cities were understood as process, characterized by flows of people, capital, goods, resources, knowledge and information (Taylor, 1997; Beaverstock et al., 2002). In a pioneering study, Beaverstock et al. (2001) used interviews with key personnel in global financial and business service firms and institutions to examine the changing relations between London and Frankfurt with the introduction of a single European currency and the decision to locate the European Central Bank in Frankfurt. The study challenged the simplistic competition model that dominated public discussion of the London-Frankfurt city dyad and brought economic practices centre stage of research on inter-city relations (see also Pain, 2008).

However, in the early 2000s, research into world city networks took a strong quantitative turn, driven by the specification of an interlocking network model' for estimating the connectivities of cities (Taylor, 2001; see also Derudder and Parnreiter, 2014). This not only provided a new approach to measuring external relations of cities in contemporary globalization (Taylor et al., 2010; Taylor and Derudder, 2016), but successfully addressed the paucity of relevant data and associated empirical deficit (Short et al., 1996). However, Watson and Beaverstock (2014, p. 415) have argued that while such quantitative studies are of significant value in mapping the changing patterns of globalization, they have less to offer to 'practice-based discussions which attempt to explain why certain socio-economic processes are located and performed in particular cities' (see also Lai, 2012).

Moreover, Parnreiter (2014) has argued that the interlocking network model carries the danger of losing some critical premises of the global/ world city concept and of diverting the analytical focus from the role of global/world cities in the world economy to a descriptive concern, namely to find the 'best' way to measure inter-city relations. While cities in general are defined by what flows through them - external relations are, as Taylor (2004, p. 2) asserts, 'the second nature of cities' - what is the first nature of global/world cities is that they are the places from where these flows are governed. Yet, although economic power is the subject matter of the global/world city concept, it lacks an adequate theorization (Jones, 2002; 
Allen, 2010). We contend that coming to grips with the 'command and control' functions of global/world cities requires an understanding of APS agency, strategies and practices.

Furthermore, Watson and Beaverstock (2014) argue that, despite recent methodological refinements (e.g. Taylor et al., 2014; Lüthi et al., 2018), the interlocking network model is unable to fully account for the complex strategies and the spatial organization of advanced producer service firms. In economic geography, studies of knowledge intensive services have emphasized how knowledge and expertise are embodied in the economic practice and performativity of labour. Professionals such as advertising creatives, consultants, lawyers, accountants or investment bankers are a service firm's main asset to achieve its strategic goals. Such work suggests that the role of APS in global capitalism needs to be understood in more nuanced and subtle terms than 'command' and 'control' (Kleibert, 2017); their business includes such activities as facilitating, switching, advising and circulating knowledge (Bassens and van Meeteren, 2015) and even persuasion, seduction or manipulation, and research needs to be more sensitive to these other modalities (Krijnen et al., 2017). As Sassen (2010, p. 158) argues, the influence of APS firms on clients' strategies is 'embedded' into the services provided. Accordingly, the power of APS is not exercised over clients, but together with them. It is a resource to empower clients vis-à-vis business partners, unions or governments (Parnreiter, 2017).

Jones (2014) identifies how recent work on relational economic geography has been characterized by a growing conceptual concern for practice as a 'means better to capture and specify the nature of agency that is caught up in the relations between economic actors' (2014, p. 610). Jones highlights two key developments that are particularly relevant in relation to the aims of this book. First, he notes how relational economic geographers have increasingly been concerned with intra-and inter-firm practices. Here, he suggests, researchers have viewed practices as 'everyday relational processes that constitute economic action and hold communities or firms together within, and in relation to, particular geographic contexts' (2014, p.611). Second, Jones notes that practice-orientated relational literature has been concerned with how industries and firms are organized through common social practices. These practices, he suggests, are those that 'legitimate, control and coordinate business activities' and which help to 'create the relational proximity (and in some cases trust) needed for firms to act at a distance in a globalized economy' (2014, p. 611).

As Watson and Beaverstock (2014, p. 418) argue, it is surprising, given the relational turn in the study of world cities, that research in this field has remained largely at odds with the shifts happening in economic geography: 'rather than grappling with agency, it is widely criticised for its structuralist 
underpinnings; rather than attempting micro-scale analysis of networks, it considers networks predominantly at the macro-scale; and rather than focusing on social actors, research focuses almost exclusively on the firm as the main analytical unit'. Insufficient attention has been paid to the actual practices of management and control exercised in global cities and the associated knowledge flows and agencies (Parnreiter, 2014). For van Meeteren and Bassens (2016, p. 64), as APS workers 'socially construct material circuits of value ..., they collectively produce the WCA [world city archipelago] as a place, a scale, a territory and a network'. Recognizing the centrality of agency is therefore, we argue, key to understanding world city networks. This opens up a number of new lines of theoretical questioning and research, including how the actual practices of management and control are exercised and why certain socio-economic processes are located and performed in particular cities.

As van Meeteren et al. (2016) suggest, global cities research today is characterized by a 'pronounced pluralism', evident through a wide variety of research topics, epistemologies and methodologies (see also Hoyler and Harrison, 2017). They note that, while some authors emphasize model-based approaches, others apply more qualitative research methods and, while some authors emphasize structure, others underline agency. They point for example to those who have built a substantial body of empirical work on how world city formation is linked to the agency of transnational elites through their practices and mobility patterns. Particularly significant in this regard has been the work of scholars such as Jonathan Beaverstock and Sarah Hall on transnational elites and skilled labour markets (Beaverstock, 2002, 2005; Beaverstock and Hall, 2012; Beaverstock et al., 2015; Hall, 2009), and James Faulconbridge on actors and knowledge transfer in the transnational firm (Faulconbridge, 2007, 2008; Faulconbridge et al., 2011). This body of work highlights how these 'elites' (re)produce micro-networks between firms, clients, cities and financial services clusters, spanning nodes in the world city network and constructing knowledge to manage across borders. As van Meeteren et al. (2016, p. 255) note, through such work, the structure of the world city network can be seen as the 'collective product of the agency' of particular actors as global city and world city network makers.

\subsection{AGENCY AND PRACTICE IN GLOBAL CITY (NETWORK) MAKING (AND UN-MAKING)}

This book consists of eight substantive chapters that have been assembled for their shared concern with providing in-depth and rigorous theoretical 
and empirical studies of the agency of economic actors in the 'making' of global cities. Each chapter contributes not only to our aim of exposing the central role of economic actors and their practices in 'making' global cities, but also to our call for a broadening of the range of methodologies that are employed in global cities research (see also Harrison and Hoyler, 2018).

In Chapter 2, Christof Parnreiter (2018) considers the role of advanced producer service firms as global city makers set in the context of two 'nonprime' global cities, Mexico City and Hamburg. Revisiting the global city concept as originally defined by Sassen (1991), Parnreiter emphasizes how the global city 'model' has been developed as an economic geography concept to comprehend the function and position of specific economic actors in certain cities in the management and in the 'command and control' of the world economy. Parnreiter operationalizes this concept by considering global cities as critical nodes in the organization and governance of global commodity chains (GCCs), highlighting how literature on GCCs has advanced a relational, actor-focused understanding of economic power. Drawing upon a qualitative methodology consisting of semi-structured interviews with professionals in both cities, working in accountancy, advertising, finance and insurance, as well as legal and management firms, Parnreiter shows how APS provide critical support to their clients in conducting global business. Within these firms, professionals assume the role of key actors in the making of the two cities as nodes in GCCs, fulfilling the 'management function' for their clients' global operations and providing commercially sensitive advice to clients designed to provide 'positive business outcomes'. Thus, he asserts that APS are the pre-eminent global city makers, while their servicing of clients is the key practice underlying global city formation.

Engaging further with global commodity chains, but focusing on a different type of economic actor, in Chapter 3 Wouter Jacobs (2018) considers commodity traders as agents of globalization. Jacobs points to three conceptual issues in the study of world city networks that warrant attention: firstly the importance of the specialization of the actors that constitute inter-city linkages; second the physicality of global networks; and finally the lack of understanding of what agents do to make or produce 'global' or 'world' cities. To address these issues, Jacobs undertakes an investigation of the economic geography of commodity trading and the role that traders play in the formation of the world city network. Through a close analysis of business cases from a large commodity trading firm, and drawing conceptually upon the work of James Vance (1970) on the mercantile model of settlement, Jacobs argues that key global cities have evolved from the practices and the physicality of their origins as trading places. He contends that in order for commodity traders to act as global agents, they prefer the agglomeration benefits offered by global cities; 
and, further, that traders subject those places involved in the extraction, production and distribution of the commodities traded, to the logic of the 'world city' through their trading practices.

Switching attention from commodities to real estate, in Chapter 4 Colin Lizieri and Daniel Mekic (2018) highlight the importance of commercial real estate as a medium by which major cities are embedded within global capital networks. Office real estate in global cities, they assert, provides the physical infrastructure that allows financial and other business service actors to operate service networks worldwide, while at the same time acting as an important investment vehicle. Drawing upon a close analysis of a proprietary database, Lizieri and Mekic examine the changing patterns of office ownership in the City of London from 1972, uncovering a shift over time in the nature of investors. They argue that global investors have underpinned liquidity that has counterbalanced poor investment performance, and point to the need to assess changes in investor type and shifts in the nationality of ownership in order to understand how investment patterns serve to integrate the City into global financial and urban networks. Further, they highlight how the presence of global brokerage firms provides a key benefit to investors in building global portfolios, and influences the flows of capital across cities. Taken together, these two types of key actors in real estate markets play a critical role in creating the functional form of the global city of London and its dynamic operation.

Continuing on the theme of real estate, in Chapter 5 David Scofield (2018) examines the market practices of APS firms, as both investors and intermediaries, in the commercial real estate markets of New York and London. Scofield focuses on intermediation in the form of brokerage, a key catalyst in the conversion of liquid capital into real estate assets. He specifically explores how local practices of broker intermediation and the individual social networks of highly placed investment managers correspond in the commercial real estate investment markets of New York and London. To do so, he employs two complementary methodologies: first, a close analysis of a unique dataset of commercial real estate transactions; and, second, social network analysis of individual (ego-centric) social capital networks of senior investment managers responsible for the acquisition of commercial real estate on behalf of major investment firms based in the US or the UK. Scofield demonstrates how brokers play a central role in the movement of capital into commercial real estate in each city, and thus assume a key role in the making of New York and London as global cities. However, he also exposes how the market behaviours that underlie the definition of these cities as 'global' retain unique differences: double brokerage is more likely to occur in London than New York, which, he suggests, offers the London broker a unique tertius role in global city making. 
Following on from these case studies of London and New York, in Chapter 6 Sakura Yamamura (2018) focuses on the third city of Sassen's (1991) original global city triad, to consider the making of transnational urban space by financial professionals in Tokyo. Yamamura points to the fact that analysis of the role of professionals in global city making has primarily focused on their function and practices within global corporations, and that such a perspective overlooks their impact as transnational individuals whose social practices play a key role in the making of global city spaces. She argues that the duality of their role as global city makers derives from these professionals being on the one hand decision-makers and business practitioners in transnational corporations, and on the other hand individuals with social practices that characterize them as transnational migrants. Yamamura adopts a qualitative research strategy consisting of semi-structured interviews with transnational professionals in the finance industry and the drawing of mental maps, to uncover social practices in formal, semi-formal and informal/private settings. Her findings suggest that professionals are directly involved in the creation of transnational 'global city spaces'. Such spaces, Yamamura asserts, are a phenomenon locally anchored in a specific global city, and yet also represent locational choices that are simultaneously embedded in corporate strategies within the global economy. Thus, professionals as economic actors represent the key binding link between the decisions and practices of global corporations and direct impacts on the local economy and on urban spaces in any given city.

In Chapter 7, Bart Lambregts, Jana Kleibert and Niels Beerepoot (2018) consider the role of the offshore services sector in the making of Mumbai as a global city. They highlight the expansion of the financial services industry into many parts of the Global South, driven by the emergence of new markets for services and the industry's desire to reduce costs. Business process outsourcing (services offshoring) has resulted in several million workers in second- and third-tier global cities producing electronically transmittable support services for global financial and other services. Lambregts et al. consider these offshored support services as a clear expression of the global integration of such cities. Drawing on qualitative data obtained from in-depth interviews with current and former senior executives in Mumbai's offshore service industry, as well as with representatives from the public sector and relevant business associations, the authors envisage the industry as a 'backstage global city maker'. They demonstrate that the offshore services industry lends support to the city's onshore finance sector, and thus to the making of Mumbai as a global city, through triggering processes of upgrading in auxiliary services, fostering local demand for financial services, bolstering the city's image 
and reputation as a financial centre, and crucially contributing to human capital formation. Thus, the authors argue that certain categories of actors who are generally not conceived of as global city makers in the Global North can assume global city making roles in cities of the Global South.

Chapters 8 and 9 perform the important task of problematizing discourses around global city 'making'. Global-local tensions and the role of governance are the central focus of Chapter 8, in which Markus Hesse (2018) considers issues of global city making and localism in Hamburg's maritime network. In opening the chapter, Hesse highlights how port institutions and port-city officials might be viewed as ideal global city makers, in that they target global flows to serve local interests. However, through an analysis of the interplay of a range of public and private economic actors in the making of Hamburg as a global (port) city, Hesse seeks to illustrate the complexities of governance in a city pursuing ambitious planning and development goals. Drawing upon qualitative data from interviews with representatives of maritime firms, port authorities and public officials, as well as document analysis of secondary data material including parliamentary documents, Hesse provides a complex case study of the dynamics of localism and globalization. Global city making, he argues, is not necessarily, and not exclusively, the business of single actors. Rather, global city making requires a particular setting - a community of practice based on shared beliefs among key actors - as well as an ideological framework, which leads to such a project coming into being. He illustrates this argument by considering the relationship between the city and a 'focal' private firm (a major shipping line). In evaluating this relationship, Hesse identifies a 'new localism', which differs from usual globalization discourses and rhetoric, and which he interprets as 'reluctance' to become fully globalized. Thus, through their planning strategies and local decision-making, the agency of local governance and public bodies in actively 'making' or 'notmaking' the global city is elucidated.

In Chapter 9, Michiel van Meeteren and David Bassens (2018) study the role of management consultancy in the failure of the Dutch bank ABN AMRO, highlighting the potential for key actors to not only 'make', but also 'un-make' the global city. Specifically, they consider the influence of APS firms on the strategic and tactical management practices of multinational organizations. The authors have assembled an impressive portfolio of primary and secondary data sources, including extensive documentation in the Dutch and English language financial press, annual reports of the bank, and an archive of ABN AMRO employee magazines, in order to undertake a historical reconstruction of key events, decisions and narratives leading up to the failure of the bank. They highlight how APS in general, and management consultancy firms in particular, act as 
important vectors to tie firms operating from semi-peripheral nodes of the world city network into financial markets centred on core global cities. Yet their account is also highly critical of management consultants as the key actors who linked ABN AMRO from a 'second-tier' global city into an industry field of global highly leveraged banks located in core global cities, and thus played a key part in the bank's demise. Their findings, van Meeteren and Bassens suggest, emphasize the power asymmetries that exist within the APS complex, which play out geographically. Thus the authors provide a 'cautionary tale' for global city makers (in this case, the Amsterdam financial centre growth coalition): buying into the narratives of global consultants for aspirational purposes, they argue, only delayed, but was unable to prevent, the further 'un-making' of Amsterdam as a global city already in decline in the field of international banking.

\subsection{A RENEWED CRITICAL AGENDA FOR GLOBAL CITIES RESEARCH}

Together, the contributions in this book not only provide sector-specific indepth accounts of the role of powerful economic actors in the making and un-making of global cities, but encourage us to think critically about the role of agency and practices in a renewed agenda for global cities research. For us, there are at least four key elements in progressing such an agenda, which recognize not only the issues raised within the contributions to this book, but also the many gaps and omissions which are unavoidable in such a project:

1. A need to incorporate perspectives on agency and practice from relational economic geography into the conceptualizing and doing of global cities research There are a number of ways in which such a project can be taken forward. One, emerging from the contributions in this book, is to undertake more detailed examinations of how different cultures of doing business may lead to a variety of different outcomes in and across different cities. The assumption within current approaches to world city network research that use firm office locations as a surrogate for flows is necessarily that practices are homogeneous on a global level, that is to say that one link between offices within a firm (assuming the link exists) has the same purpose, meaning and intensity as every other link. In reality, of course, the situation is much more nuanced; as David Scofield (2018) highlights in his study of real estate, behaviours that underlie the definition of cities as 'global' are not identical, but rather retain unique differences that result in actors in 
similar positions operating differently. Further, as Sassen (2018, p. 3) notes, the process of global city making is 'centred at the intersection of different types of emergent global economic circuits with distinct contents', which vary across economic sectors. Sassen sees in this process the making of a 'distinctive "urban knowledge capital", a kind of capital that could only be made via a mix of conditions among which was the city itself with its diverse knowledge and experiential vectors'. We would argue that one cannot understand these vectors without insight into the agency and practices of those carrying, using and transferring these knowledges and experiences.

2. A need to specify the practices underlying global city making Practices are neither unintentional nor value-free. Rather, they serve distinct purposes - in the case of APS firms in global/world cities, these are related to the management and governance of their clients' commodity chains. Relations between APS firms and their clients are embedded into, and serve, the hierarchical relations which APS firms' clients maintain in their production networks (Parnreiter, 2017). In advocating a re-orientation of attention to practices in global city formation, we also encourage doing so in a way that recovers the critical intentions of the early global/world city research (Hoyler and Harrison, 2017) and that explores 'how cities and the classes within them achieve control over other regions' (Roberts, 1986, p. 459; emphasis added).

3. A need to recognize the diversity of actors involved in global city making While the contributions in this book focus on powerful economic actors across a range of APS, the importance of actors in other sectors must not, indeed cannot, be overlooked. Economic practices and strategic decision-making should not be considered in isolation; they are embedded in wider economic, social and political relations each with their own sets of critical actors (Hall, 2018). One might investigate, for example, key actors in city governance and marketing: Hesse (2018) explores the nature of relations between the city (public) and firm (private) as collective entities but key individual actors such as city mayors can also play an important role in decision making (Ponzini and Rossi, 2010; McNeill, 2014). One could also consider key actors in architecture, urban planning and design (McNeill, 2009; Ren, 2011; Rapoport, 2015; Sklair, 2017), arts and culture (Kong et al., 2015), and in the globalized built environment more generally (McNeill, 2015), to name but a few. It is also important, of course, to critically interrogate the privileging of elite labour in accounts of global city making, and to consider notions of agency as they relate to complex divisions of skilled and unskilled labour. In the prologue to this book, Sassen (2018, p.3) emphasizes the importance of lowly rewarded tasks as 'maintaining a 
strategic infrastructure' that 'ensure[s] maximum performance by highincome talent'. Yet, as Wills et al. (2010) highlight in their examination of new migrant divisions of labour in London, low-paid migrant workers are not only key actors in making global cities work, but are themselves key agents in the remaking of the city, through, for example, their impact on global city labour markets.

4. A need to account for the role of actors and practices not only in the making but also in the un-making of global cities Conceptualizing global city making as a dynamic and complex process opens up two further important lines of research. First, it requires us to consider the diversity of locations in which these processes occur. As Sassen (2018, p. 1) notes, the term 'global city' was not intended to refer to a whole city, but rather is 'a production function inserted in complex existing cities'. She argues that today one might identify 100 plus global cities, with even minor global cities inventing new instruments and building new markets. In this book, for example, Lambregts et al. (2018) emphasize how services offshoring has resulted in several million workers in second- and third-tier global cities producing electronically transmittable support services for global financial and other services. Particularly relevant to the aims of this book is Krijnen et al.'s (2017) assertion that little of the agency-centred literature on APS professionals has engaged with cities beyond the core of the world city network, or on the 'boundary-spanning' work through which cities beyond the core are incorporated in global accumulation processes.

Second, we consider it crucial to challenge teleological notions and aspirational discourses regarding the immanent 'becoming' of global cities through such processes (Leon, 2017). Processes can also be disruptive and result in the 'un-making' of global cities, as illustrated in this book with the decline of Amsterdam as centre for international banking (van Meeteren and Bassens, 2018; see also Engelen, 2007; Faulconbridge et al., 2007), or as witnessed in the demise of Reykjavik as a banking centre in the wake of the global financial crisis (Derudder et al., 2011). This 'un-making' unfolds through relational networks of practice and dependency resulting in wider systemic impacts. Wójcik (2013a) for example, in his examination of the 'dark side of NY-LON', argues that the commonality, complementarity and connectivity between New York and London as the two leading global financial centres resulted in the formation of a powerful 'axis' in which the global financial crisis of 2007-09 was rooted. Revisiting agency in relation to financial centres, Wójcik points in particular to the role of regulatory bodies and industrial lobbying associations, which not only function in specific places, but which are also 'plugged into key 
spatial networks' (2013a, p. 2748; see also Wójcik, 2013b). The current debate on Brexit and its implications for London in contrast provides an example of potential un-making through geopolitical and geoeconomic 'separation and disentanglement' (Dörry, 2017, p. 1). With its emphasis on the role of political actors in shaping financial centre relations (Lavery et al., 2018) this debate brings to the fore 'questions of power and politics within the global economy' (Hall, 2018, p. 194) as key aspects of global city making and un-making.

We see the four elements highlighted above as crucial parts of a renewed, critical and potentially more progressive agenda for global cities and world city network research, focused around agency and practice. Our hope is that this book will act as both inspiration and reference point for researchers to progress this agenda, and to address its many conceptual and methodological challenges.

\section{REFERENCES}

Allen, J. (2010), 'Powerful city networks: More than connections, less than domination and control', Urban Studies, 47 (13), 2895-2911.

Bassens, D. and M. van Meeteren (2015), 'World cities under conditions of financialized globalization: Towards an augmented world city hypothesis', Progress in Human Geography, 39 (6), 752-775.

Beaverstock, J.V. (2002), 'Transnational elites in global cities: British expatriates in Singapore's financial district', Geoforum, 33 (4), 525-538.

Beaverstock, J.V. (2005), 'Transnational elites in the city: British highly-skilled inter-company transferees in New York City's financial district', Journal of Ethnic and Migration Studies, 31 (2), 245-268.

Beaverstock, J.V. and S. Hall (2012), 'Competing for talent: Global mobility, immigration and the City of London's labour market', Cambridge Journal of Regions, Economy and Society, 5 (2), 271-288.

Beaverstock, J.V., J.R. Faulconbridge and S.J.E. Hall (2015), The Globalization of Executive Search: Professional Service Strategy and Dynamics in the Contemporary World, London: Routledge.

Beaverstock, J.V., M. Hoyler, K. Pain and P.J. Taylor (2001), Comparing London and Frankfurt as World Cities: A Relational Study of Contemporary Urban Change, London: Anglo-German Foundation for the Study of Industrial Society.

Beaverstock, J.V., M.A. Doel, P.J. Hubbard and P.J. Taylor (2002), 'Attending to the world: Competition, cooperation and connectivity in the world city network', Global Networks, 2 (2), 111-132.

Boussebaa, M. (2015), 'Control in the multinational enterprise: The polycentric case of global professional service firms', Journal of World Business, 50, 696-703.

Derudder, B. and C. Parnreiter (2014), 'Introduction: The interlocking network model for studying urban networks: Outline, potential, critiques, and ways forward', Tijdschrift voor Economische en Sociale Geografie, 105 (4), 373-386. 
Derudder, B., M. Hoyler and P. Taylor (2011), 'Goodbye Reykjavik: International banking centres and the global financial crisis', Area, 43 (2), 173-182.

Derudder, B., M. Hoyler, P.J. Taylor and F. Witlox (eds) (2012), International Handbook of Globalization and World Cities, Cheltenham, UK and Northampton, MA, USA: Edward Elgar Publishing.

Dörry, S. (2017), 'The geo-politics of Brexit, the euro and the City of London', Geoforum, 85, 1-4.

Engelen, E. (2007), “'Amsterdamned"? The uncertain future of a financial centre', Environment and Planning A, 39 (6), 1306-1324.

Faulconbridge, J.R. (2007), 'London's and New York's advertising and law clusters and their networks of learning: Relational analyses with a politics of scale?', Urban Studies, 44 (9), 1635-1656.

Faulconbridge, J.R. (2008), 'Managing the transnational law firm: A relational analysis of professional systems, embedded actors, and time-space-sensitive governance', Economic Geography, 84 (2), 185-210.

Faulconbridge, J.R., E. Engelen, M. Hoyler and J.V. Beaverstock (2007), 'Analysing the changing landscape of European financial centres: The role of financial products and the case of Amsterdam', Growth and Change, 38 (2), 279-303.

Faulconbridge, J.R., J.V. Beaverstock, C. Nativel and P.J. Taylor (2011), The Globalization of Advertising: Agencies, Cities and Spaces of Creativity, London: Routledge.

Friedmann, J. (1986), 'The world city hypothesis', Development and Change, 17 (1), 69-83.

Hall, S. (2009), 'Financialised elites and the changing nature of finance capitalism: Investment bankers in London's financial district', Competition \& Change, 13 (2), 173-189.

Hall, S. (2018), 'Placing politics and power within the making of global cities', in M. Hoyler, C. Parnreiter and A. Watson (eds), Global City Makers: Economic Actors and Practices in the World City Network, Cheltenham, UK and Northampton, MA, USA: Edward Elgar Publishing, pp. 192-198.

Hanssens, H., B. Derudder and F. Witlox (2012), 'Managing organizational and geographical complexity: The "positionality" of advanced producer services in the globalizing economies of metropolitan regions', Erdkunde, 66 (1), 45-55.

Hanssens, H., B. Derudder, P.J. Taylor, M. Hoyler, P. Ni, J. Huang, X. Yang and F. Witlox (2011), 'The changing geography of globalized service provision, 2000-2008', The Service Industries Journal, 31 (14), 2293-2307.

Harrison, J. and M. Hoyler (eds) (2018), Doing Global Urban Research, London: Sage.

Hesse, M. (2018), 'Focal firms, grand coalitions or global city makers? Globalization vs. new localism in Hamburg's maritime network', in M. Hoyler, C. Parnreiter and A. Watson (eds), Global City Makers: Economic Actors and Practices in the World City Network, Cheltenham, UK and Northampton, MA, USA: Edward Elgar Publishing, pp. 151-169.

Hoyler, M. and J. Harrison (2017), 'Global cities research and urban theory making', Environment and Planning A, 49 (12), 2853-2858.

Jacobs, W. (2014), 'Rotterdam and Amsterdam as trading places? In search of the economic-geographical nexus between global commodity chains and world cities', Tijdschrift voor Economische en Sociale Geografie, 105 (4), 483-491.

Jacobs, W. (2018), 'Commodity traders as agents of globalization', in M. Hoyler, C. Parnreiter and A. Watson (eds), Global City Makers: Economic Actors and 
Practices in the World City Network, Cheltenham, UK and Northampton, MA, USA: Edward Elgar Publishing, pp. 41-59.

Jones, A. (2002), "The "global city" misconceived: The myth of "global management" in transnational service firms', Geoforum, 33 (3), 335-350.

Jones, A. (2014), 'Geographies of production I: Relationality revisited and the "practice shift" in economic geography', Progress in Human Geography, 38 (4), 605-615.

Kleibert, J. (2017), 'On the global city map, but not in command? Probing Manila's position in the world city network', Environment and Planning A, 49 (12), 2897-2915.

Kong, L., C. Chia-ho and C. Tsu-Lung (2015), Arts, Culture and the Making of Global Cities: Creating New Urban Landscapes in Asia, Cheltenham, UK and Northampton, MA, USA: Edward Elgar Publishing.

Krijnen, M., D. Bassens and M. van Meeteren (2017), 'Manning circuits of value: Lebanese professionals and expatriate world-city formation in Beirut', Environment and Planning A, 49 (12), 2878-2896.

Lai, K. (2012), 'Differentiated markets: Shanghai, Beijing and Hong Kong in China's financial centre network', Urban Studies, 49 (6), 1275-1296.

Lambregts, B., J. Kleibert and N. Beerepoot (2018), 'The making of Mumbai as a global city: Investigating the role of the offshore services sector', in M. Hoyler, C. Parnreiter and A. Watson (eds), Global City Makers: Economic Actors and Practices in the World City Network, Cheltenham, UK and Northampton, MA, USA: Edward Elgar Publishing, pp. 124-150.

Lavery, S., S. McDaniel and D. Schmid (2018), 'New geographies of European financial competition? Frankfurt, Paris and the political economy of Brexit', Geoforum, 94, 72-81.

Leon, J.K. (2017), 'Global cities at any cost: Resisting municipal mercantilism', City, 21 (1), 6-24.

Lizieri, C. and D. Mekic (2018), 'Real estate and global capital networks: Drilling into the City of London', in M. Hoyler, C. Parnreiter and A. Watson (eds), Global City Makers: Economic Actors and Practices in the World City Network, Cheltenham, UK and Northampton, MA, USA: Edward Elgar Publishing, pp. 60-82.

Lüthi, S., A. Thierstein and M. Hoyler (2018), 'The world city network: Evaluating top-down versus bottom-up approaches', Cities, 72, 287-294.

McNeill, D. (2009), The Global Architect: Firms, Fame and Urban Form, New York: Routledge.

McNeill, D. (2014), 'Mayors and the representation of urban politics', in M. Davidson and D. Martin (eds), Urban Politics: Critical Approaches? London: Sage, pp. $100-111$.

McNeill, D. (2015), 'Tracking the global urbanists', Global Networks, 15 (3), 379-384.

Pain, K. (2008), 'Spaces of practice in advanced business services: Rethinking London-Frankfurt relations', Environment and Planning D: Society and Space, 26 (2), 264-279.

Parnreiter, C. (2010), 'Global cities in global commodity chains: Exploring the role of Mexico City in the geography of global economic governance', Global Networks, 10 (1), 35-53.

Parnreiter, C. (2014), 'Network or hierarchical relations? A plea for redirecting attention to the control functions of global cities', Tijdschrift voor Economische en Sociale Geografie, 105 (4), 398-411.

Parnreiter, C. (2015), 'Managing and governing commodity chains: The role of 
producer service firms in the secondary global city of Hamburg', Die Erde, 146 (1), 1-15.

Parnreiter, C. (2017), 'Global cities and the geographical transfer of value', Urban Studies, DOI: 10.1177/0042098017722739.

Parnreiter, C. (2018), 'Producer service firms as global city makers: The cases of Mexico City and Hamburg', in M. Hoyler, C. Parnreiter and A. Watson (eds), Global City Makers: Economic Actors and Practices in the World City Network, Cheltenham, UK and Northampton, MA, USA: Edward Elgar Publishing, pp. $23-40$.

Ponzini, D. and U. Rossi (2010), 'Becoming a creative city: The entrepreneurial mayor, network politics and the promise of an urban renaissance', Urban Studies, 47 (5), 1037-1057.

Rapoport, E. (2015), 'Globalising sustainable urbanism: The role of international masterplanners', Area, 47 (2), 110-115.

Ren, X. (2011), Building Globalization: Transnational Architecture Production in Urban China, Chicago: The University of Chicago Press.

Roberts, B. (1986), 'Review of Timberlake, M., Urbanization in the WorldEconomy', International Journal of Urban and Regional Research, 10 (3), 458-459.

Robinson, J. (2006), Ordinary Cities: Between Modernity and Development, London: Routledge.

Rossi, E.C., J.V. Beaverstock and P.J. Taylor (2007), 'Transaction links through cities: "Decision cities" and "service cities" in outsourcing by leading Brazilian firms', Geoforum, 38 (4), 628-642.

Sassen, S. (1991), The Global City: New York, London, Tokyo, Princeton, NJ: Princeton University Press.

Sassen, S. (2001), The Global City: New York, London, Tokyo (2nd edition), Princeton, NJ: Princeton University Press.

Sassen, S. (2010), 'Global inter-city networks and commodity chains: Any intersections?', Global Networks, 10 (1), 150-163.

Sassen, S. (2018), 'The global city: Enabling economic intermediation and bearing its costs', in M. Hoyler, C. Parnreiter and A. Watson (eds), Global City Makers: Economic Actors and Practices in the World City Network, Cheltenham, UK and Northampton, MA, USA: Edward Elgar Publishing, pp. 1-4.

Scofield, D. (2018), 'Global cities, local practices: Intermediation in the commercial real estate markets of New York City and London', in M. Hoyler, C. Parnreiter and A. Watson (eds), Global City Makers: Economic Actors and Practices in the World City Network, Cheltenham, UK and Northampton, MA, USA: Edward Elgar Publishing, pp. 83-105.

Short, J.R., Y. Kim, M. Kuus and H. Wells (1996), 'The dirty little secret of world cities research: Data problems in comparative analysis', International Journal of Urban and Regional Research, 20 (4), 697-717.

Sklair, L. (2017), The Icon Project: Architecture, Cities, and Capitalist Globalization, New York: Oxford University Press.

Taylor, P.J. (1997), 'Hierarchical tendencies amongst world cities: A global research proposal', Cities, 14 (6), 323-332.

Taylor, P.J. (2001), 'Specification of the world city network', Geographical Analysis, 33 (2), 181-194.

Taylor, P.J. (2004), World City Network: A Global Urban Analysis, London: Routledge. 
Taylor, P.J. and B. Derudder (2016), World City Network: A Global Urban Analysis (2nd edition), London: Routledge.

Taylor, P.J., M. Hoyler and R. Verbruggen (2010), 'External urban relational process: Introducing central flow theory to complement central place theory', Urban Studies, 47 (13), 2803-2818.

Taylor, P.J., B. Derudder, J. Faulconbridge, M. Hoyler and P. Ni (2014), 'Advanced producer service firms as strategic networks, global cities as strategic places', Economic Geography, 90 (3), 267-291.

Taylor, P.J., P. Ni, B. Derudder, M. Hoyler, J. Huang and F. Witlox (eds) (2011), Global Urban Analysis: A Survey of Cities in Globalization, London: Earthscan.

Van Meeteren, M. and D. Bassens (2016), 'World cities and the uneven geographies of financialization: Unveiling stratification and hierarchy in the world city archipelago', International Journal of Urban and Regional Research, 40 (1), 62-81.

Van Meeteren, M. and D. Bassens (2018), 'Chasing the phantom of a "global endgame": The role of management consultancy in the narratives of pre-failure ABN AMRO', in M. Hoyler, C. Parnreiter and A. Watson (eds), Global City Makers: Economic Actors and Practices in the World City Network, Cheltenham, UK and Northampton, MA, USA: Edward Elgar Publishing, pp. 170-191.

Van Meeteren, M., B. Derudder and D. Bassens (2016), 'Can the straw man speak? An engagement with postcolonial critiques of "global cities research", Dialogues in Human Geography, 6 (3), 247-267.

Vance, J.E. (1970), The Merchant's World: The Geography of Wholesaling, Englewood Cliffs, NJ: Prentice-Hall.

Watson, A. and J.V. Beaverstock (2014), 'World city network research at a theoretical impasse: On the need to re-establish qualitative approaches to understanding agency in world city networks', Tijdschrift voor Economische en Sociale Geografie, 105 (4), 412-426.

Wills, J., K. Datta, Y. Evans, J. Herbert, J. May and C. McIlwaine (2010), Global Cities at Work: New Migrant Divisions of Labour, London: Pluto Press.

Wójcik, D. (2013a), 'The dark side of NY-LON: Financial centres and the global financial crisis', Urban Studies, 50 (13), 2736-2752.

Wójcik, D. (2013b), 'Where governance fails: Advanced business services and the offshore world', Progress in Human Geography, 37 (3), 330-347.

Yamamura, S. (2018), 'The making of transnational urban space: Financial professionals in the global city Tokyo', in M. Hoyler, C. Parnreiter and A. Watson (eds), Global City Makers: Economic Actors and Practices in the World City Network, Cheltenham, UK and Northampton, MA, USA: Edward Elgar Publishing, pp. 106-123. 